\title{
Intelligent Pollution Mask: a Lifesaving Device
}

\author{
Dhruv Sharma ${ }^{1}$, R. Jahnavi ${ }^{1}$, Vimlesh Singh ${ }^{1}$ and Mohit Verma ${ }^{1,2, *}$ \\ 1Department of Electronics \& Communication Engineering, Manav Rachna International Institute of Research \\ \&Studies, Faridabad 121001, India; d9781045657@gmail.com, Rjahnavi1904@gmail.com, vimlesh.fet@mriu.co.in \\ ${ }^{2}$ Accendere CL Educate, New Delhi 110044, India; mohit.verma@accendere.co.in
}

\begin{abstract}
Background/objectives: The air pollution level is increasing immensely because of several issues, such as emission of highly inflammable gases from factories, an alarming rise in the use of petrol and diesel vehicles for personal commute, and various other sources that generate smoke; all of this have an seriously harmful impact on human health and are responsible for various diseases. Therefore, the objective of this article is to propose an improved and handy system of mask wearing which will help reduce the hazardous effects of air pollution on human health. Methods/findings: After analysing and comparing several products available in the market, a handy and easy-functioning Adriano-based intelligent pollution mask is proposed. This particular design of mask can detect and filter hazardous air pollutants using various sensors. It can also indicate and communicate the pollution level through an inbuilt app with other mask-wearers, including information about which areas to avoid that have very high air pollution. Improvements/application: Because it can detect and filter out several toxic gasses, this product is can be a great solution for preventing the harmful/dangerous effects of air pollution on the human body and, consequently, preventing diseases resulting from breathing highly polluted and saving many lives.
\end{abstract}

Keywords: Air Pollution, PM2.5, PM10, Air pollutants, Mask.

\section{Introduction}

Our Earth is about 4.5 billion years old, and naturally that has to account for some of the environmental issues, including natural calamities brought about because of changes in climate, and other disasters and environmental calamities that we humans alone are to be blamed for and which we face today. 1 The advancement in civilisation and industrial revolution led to a decline in agrarian lifestyle and an increased outmigration of people from rural/village areas to urban regions such as townships and cities and metros. As much as $50 \%$ of the population lives in urban regions today and, as a result, cities all over the world have become woefully bereft of adequate infrastructure and sanitation facilities that can support or keep pace with the explosion in urban population. In the case of India and China, cities like Mumbai and Beijing are home to more than 20 million people. Another shocking example is Delhi, whose population is predicted to touch 40 million in the next 10 years.
As discussed earlier, the human evolution and later modernisation efforts to fulfil the need to lead a better, physically less taxing life and improved personal commutation and transportation of essential goods and commodities brought about numerous changes through industrialisation, which in turn led to building factories, manufacturing transport vehicles, construction of highrise buildings and so on, not realising the adverse effects all of this were to have on the environment and the very air we breathe. The growth in industrialisation has on the one hand improved the standard of life rapidly and vastly, yet there was a price to be paid, especially in the form of air pollution. Industrialisation has unleashed such a havoc on the natural environment that it has put our very existence into question, including the dangerous rise in global warming and rising sea level that threatens to submerge major cities built along the shorelines.

In India, situation has worsened. According to the WHO report, as many as 12 lakh deaths occur every year that are a direct result of lung diseases, respiratory

${ }^{*}$ Author for correspondence 
disorders, and heart diseases caused by air pollution. It is also claimed that Delhi is the most polluted city in the country. $\underline{2}$

The objective of this article is to give an overview of air pollution and different types of major air pollutants. The rest of this article is organised in the following way. Section II presents a discussion on major air pollutants and the numerous health issues caused by them. Section III talks about present major initiatives being taken and solutions being implemented to tackle air pollution. Section IV presents some of the solutions proposed by the authors to bring air pollution under control.

\section{Various Pollutants in Air and Major Health Issues}

Air gets polluted when harmful pollutants such as particulates and biological molecules combine with the surrounding fresh air and make it polluted and thus difficult to breathe. These harmful air pollutants are responsible for major diseases like asthma, heart diseases, lung cancer, pneumonia, cardiovascular problems, neurological problems, and premature death.

Although there are a plethora of harmful pollutants present in the atmosphere, about six of them are extremely harmful and mostly responsible for deaths that occur due to air pollution. These pollutants are nicknamed as 'Criteria-Air Pollutants' and are commonly used for describing air pollution. They are carbon monoxide, lead, nitrogen dioxide, ozone, particulate matter, and sulphur dioxide. Table 1 explains the sources and effects of these pollutants. $\underline{\underline{3}}$

\section{Getting Aware of Air Pollution Values}

Breathing is the very basic aspect to our survival. Unfortunately, people are not aware about the pollution level in the air, because these air pollutants are so small that you cannot see them through naked eyes and don't realise the damage they cause to the body. Since at an individual level, there isn't much an ordinary person can do to curtail pollution, it then becomes the sole responsibility of authorities and government regulatory bodies to bring awareness among public about the poor quality of air. To estimate the quality of the air, the Air Quality Index (AQI) is introduced.
Air Quality Index is a group of some numbers divided into different categories that indicate how much polluted is the surrounding air. Each group means a different level of air pollution, ranging from good to hazardous. Different countries use different Air Quality Indices.

- In the United States, AQI was introduced by the U.S. Environmental Protection Agency back in 1968, and their AQI is divided into six different categories. The real-time data on monitoring and forecasting pollution levels based on the Air Quality Indices are available from EPA's official website https://www.airnow. gov/ and some of them are presented in Table 2.

- In Canada, Air Quality Reporting is done with the help of Provincial Air Quality Indices. Canada has its own air quality index called Air Quality Health Index (AQHI). AQIH is a program that has been created in public interest and is coordinated by Health Canada and Environment Canada. The AQIH project was originally launched by British Columbia Interior and Nova Scotia in 2005, and is currently active in across 103 communities of Canada. The program has four different categories, and numbers ranging from 1 to 10 and above are used to rank the prevailing pollution levels. The data are shown in Table 3. 4

- China's Air Quality Index is divided into six categories as shown in Table 4. Six atmospheric pollutants are considered: PM2.5, PM10, sulphur dioxide $\left(\mathrm{SO}_{2}\right)$, nitrogen dioxide $\left(\mathrm{NO}_{2}\right)$, ozone $\left(\mathrm{O}_{3}\right)$, and carbon monoxide (CO). China's Ministry of Environment Protection (MEP) holds the responsibility of measuring country's air pollution levels. Table 4 shows the six categories of index along with their health implications. $\underline{\underline{5}}$

- Talking about India, in October 2014, a National Air Quality Index, as part of an initiative named Swachh Bharat Yojana, was introduced by Mr. Prakash Javedkar, the Minister of Environment, Forests \& Climate Change. The Central Pollution Control Board and State Pollution Control Boards are jointly operating the National Air Monitoring Program. Currently, this program is monitoring 240 major cities in the country with a total of 342 monitoring systems. The index takes into consideration eight major air pollutants: PM10, PM2.5, nitrogen dioxide $\left(\mathrm{NO}_{2}\right)$, ozone $\left(\mathrm{O}_{3}\right)$, carbon monoxide $(\mathrm{CO})$, sulphur dioxide $\left(\mathrm{SO}_{2}\right)$, ammonia $\left(\mathrm{NH}_{3}\right)$, and lead $(\mathrm{Pb})$. India's Air Quality Index is taking eight pollutants into consideration, whereas all the major countries like the United States, Canada, and 
Table 1. Enlisted pollutants, their sources and effects

\begin{tabular}{|c|c|c|}
\hline Pollutants & Sources & Effects \\
\hline $\begin{array}{l}\text { OZONE - it is an Inorganic gas } \\
\text { having three oxygen molecules } \\
\text { aligned together in a bent symmetry. } \\
\text { It is present mostly in Stratosphere, } \\
\text { where it absorbs all UV radiations. } \\
\text { It is a strong oxidant used in many } \\
\text { oxidant-related industries like in } \\
\text { lubricating oil field. So it is also } \\
\text { present in lowest part of atmosphere } \\
\text { which is troposphere, as industry } \\
\text { emit ozone as a waste product. }\end{array}$ & $\begin{array}{l}\text { Ozone present in stratosphere is not } \\
\text { harmful as it stops UV radiations from } \\
\text { entering earth's atmosphere. Ozone present } \\
\text { in troposphere mixes with other gases and } \\
\text { produces smog. Smog is a harmful toxic gas } \\
\text { which effects breathing habits and causes } \\
\text { pain in eyes. This ozone comes from factories } \\
\text { using ozone, which emit their waste as ash } \\
\text { from chimneys. }\end{array}$ & $\begin{array}{l}\text { Ozone in troposphere is responsible for } \\
\text { a number of health problems. Ozone can } \\
\text { lead to more frequent asthma attacks } \\
\text { in people who have asthma and can } \\
\text { cause sore throats, coughs and breathing } \\
\text { difficulty. It may even lead to premature } \\
\text { death. } \\
\text { Ozone can also hurt plants and crops. }\end{array}$ \\
\hline $\begin{array}{l}\text { Carbon monoxide - a gas that comes } \\
\text { from burning of fossil fuels, mostly } \\
\text { in cars. It cannot be seen or smelled. }\end{array}$ & $\begin{array}{l}\text { Carbon monoxide is released when engines } \\
\text { burn fossil fuels. Emissions are higher when } \\
\text { engines are not tuned properly, and when } \\
\text { fuel is not completely burned. Cars emit a lot } \\
\text { of carbon monoxide. } \\
\text { Furnaces and heaters in the home also emit } \\
\text { high concentrations of carbon monoxide. }\end{array}$ & $\begin{array}{l}\text { Carbon monoxide makes it hard to get } \\
\text { oxygen properly. Exposure to carbon } \\
\text { monoxide makes people feel dizzy and } \\
\text { tired and gives them headaches. In high } \\
\text { concentrations it is fatal. Elderly people } \\
\text { with heart disease are hospitalised more } \\
\text { often when they are exposed to higher } \\
\text { amounts of carbon monoxide. }\end{array}$ \\
\hline $\begin{array}{l}\text { Nitrogen dioxide - a reddish-brown } \\
\text { gas that comes from the burning of } \\
\text { fossil fuels. It has a strong smell at } \\
\text { high levels. }\end{array}$ & $\begin{array}{l}\text { Nitrogen dioxide mostly comes from power } \\
\text { plants and cars. } \\
\text { Nitrogen dioxide is formed in two ways - } \\
\text { when nitrogen in the fuel is burned or when } \\
\text { nitrogen in the air reacts with oxygen at very } \\
\text { high temperatures. } \\
\text { Nitrogen dioxide can also react in the } \\
\text { atmosphere to form ozone, acid rain and } \\
\text { particles. }\end{array}$ & $\begin{array}{l}\text { High levels of nitrogen dioxide exposure } \\
\text { can give people coughs and make them } \\
\text { feel short of breath. People who are } \\
\text { exposed to nitrogen dioxide for a long } \\
\text { time have a higher chance of getting } \\
\text { respiratory infections. } \\
\text { Nitrogen dioxide reacts in the atmosphere } \\
\text { to form acid rain which harms plants and } \\
\text { animals. }\end{array}$ \\
\hline $\begin{array}{l}\text { Particulate matter - solid or liquid } \\
\text { matter, suspended in the air. } \\
\text { Usually the air particles must be less } \\
\text { than } 0.1 \mathrm{~mm} \text { wide and as small as } \\
0.00005 \mathrm{~mm} \text { in diameter. }\end{array}$ & $\begin{array}{l}\text { Particulate matter can be divided into two } \\
\text { types - coarse particles and fine particles. } \\
\text { Coarse particles are formed from sources } \\
\text { like road dust, sea spray and construction } \\
\text { while fine particles are formed when fuels is } \\
\text { burned in automobiles and power plants. }\end{array}$ & $\begin{array}{l}\text { Particulate matter is small enough that } \\
\text { can enter the lungs and cause health } \\
\text { problem. Some of these problems include } \\
\text { more frequent asthma attacks, respiratory } \\
\text { problems and premature deaths. }\end{array}$ \\
\hline $\begin{array}{l}\text { Sulphur dioxide - a corrosive gas } \\
\text { that cannot be seen or smelled at } \\
\text { low levels but can have a 'rotten egg' } \\
\text { smell at high levels }\end{array}$ & $\begin{array}{l}\text { Sulphur dioxide mostly comes from the } \\
\text { burning of coal or oil in power plants. It also } \\
\text { comes from factories belongs to chemicals, } \\
\text { papers, or fuel. } \\
\text { Like nitrogen dioxide, sulphur dioxide reacts } \\
\text { in the atmosphere to form acid rain and } \\
\text { articles. }\end{array}$ & $\begin{array}{l}\text { Sulphur dioxide exposure can affect } \\
\text { people who have asthma or emphysema } \\
\text { by making it more difficult for them to } \\
\text { breathe. } \\
\text { It can also irritate people's eyes, noses and } \\
\text { throats. } \\
\text { Sulphur dioxide also harms trees and } \\
\text { crops, damage buildings and makes it } \\
\text { harder for people to see long distances. }\end{array}$ \\
\hline $\begin{array}{l}\text { Lead - a blue-grey metal that is very } \\
\text { toxic and is found in a number of } \\
\text { forms and locations }\end{array}$ & $\begin{array}{l}\text { Lead mainly comes from automobiles. It } \\
\text { also emerges from power plants and other } \\
\text { industrial sources. } \\
\text { Paint is also an important source of lead. } \\
\text { Again, lead in old pines can also be source of } \\
\text { lead in drinking water. }\end{array}$ & $\begin{array}{l}\text { High amount of leads can be dangerous for } \\
\text { small children and can lead them to lower } \\
\text { IQs and kidney problems. } \\
\text { For adults, exposure to lead can increase } \\
\text { the chance of having heart attacks or } \\
\text { strokes. }\end{array}$ \\
\hline
\end{tabular}


Table 2. Air quality index values with their colour representation of USA

\begin{tabular}{|l|l|l|}
\hline $\begin{array}{l}\text { Air quality index(AQI) } \\
\text { values }\end{array}$ & $\begin{array}{l}\text { Level of health } \\
\text { concern }\end{array}$ & Colours \\
\hline 0 to 50 & Good & Green \\
\hline 51 to 100 & Moderate & Yellow \\
\hline 101 to 150 & $\begin{array}{l}\text { Unhealthy for } \\
\text { sensitive groups }\end{array}$ & Orange \\
\hline 151 to 200 & Unhealthy & Red \\
\hline 201 to 300 & Very unhealthy & Purple \\
\hline 301 to 500 & Hazardous & Maroon \\
\hline
\end{tabular}

Table 3. Air quality health index representation with their risks of Canada

\begin{tabular}{|l|l|l|}
\hline $\begin{array}{l}\text { Air quality } \\
\text { health } \\
\text { index }\end{array}$ & $\begin{array}{l}\text { Health } \\
\text { risk }\end{array}$ & Health messages \\
\hline $1-3$ & Low & $\begin{array}{l}\text { Ideal air quality for outdoor } \\
\text { activities. }\end{array}$ \\
\hline $4-6$ & Moderate & $\begin{array}{l}\text { People might get symptoms such } \\
\text { as coughing and throat irritation. }\end{array}$ \\
\hline $7-10$ & High & $\begin{array}{l}\text { Consider reducing or rescheduling } \\
\text { symptoms such as coughing and } \\
\text { throat irritation. }\end{array}$ \\
\hline Above 10 & Very high & $\begin{array}{l}\text { Reduce or reschedule strenuous } \\
\text { activities outdoors especially if } \\
\text { you experience symptoms such as } \\
\text { coughing and throat irritation. }\end{array}$ \\
\hline
\end{tabular}

China take at most six pollutants into consideration. Given in Table 5 is the Index with health implications in each category. $\underline{6}$
Table 4. Air quality health index representation with their risks of China

\begin{tabular}{|l|l|l|}
\hline AQI & Air quality & Health implications \\
\hline $0-50$ & Excellent & No air pollution \\
\hline $51-100$ & Good & $\begin{array}{l}\text { Few hypersensitive individuals } \\
\text { should reduce the time of their } \\
\text { outdoor activities. }\end{array}$ \\
\hline $101-150$ & $\begin{array}{l}\text { Lightly } \\
\text { polluted }\end{array}$ & $\begin{array}{l}\text { Slight irritations may occur, } \\
\text { children and those who have } \\
\text { breathing or heart problems } \\
\text { should reduce outdoor exercise. }\end{array}$ \\
\hline $151-200$ & $\begin{array}{l}\text { Moderately } \\
\text { polluted }\end{array}$ & $\begin{array}{l}\text { Irritations may occur, and it } \\
\text { may have an impact on healthy } \\
\text { people's heart and/ or respiratory } \\
\text { system, so all people should } \\
\text { reduce the time for outdoor } \\
\text { exercise. }\end{array}$ \\
\hline 201-300 & $\begin{array}{l}\text { Heavily } \\
\text { polluted }\end{array}$ & $\begin{array}{l}\text { Healthy people will be noticeably } \\
\text { effected. People with breathing or } \\
\text { heart problems will lack exercise } \\
\text { tolerance. Patients, children and } \\
\text { elders should remain indoors. }\end{array}$ \\
\hline Above 300 & $\begin{array}{l}\text { Severely } \\
\text { polluted }\end{array}$ & $\begin{array}{l}\text { Even healthy people will lack } \\
\text { endurance during activities. } \\
\text { There may be strong irritations } \\
\text { and symptoms. So all people } \\
\text { should avoid outdoor activities. }\end{array}$ \\
\hline
\end{tabular}

Apart from making people aware about air pollution, it is also necessary to find solutions and take actions for reducing the harmful effects of air pollution. Making people aware of the effects of air pollution helps with reducing air pollution since without active collaboration of people, nothing much can be done. Current global

Table 5. Air quality health index representation with their risks of India

\begin{tabular}{|l|l|l|}
\hline $\begin{array}{l}\text { Air } \\
\text { quality } \\
\text { index }\end{array}$ & Air quality & Associated health impacts \\
\hline $0-50$ & Good & Minimal impact \\
\hline $51-100$ & Satisfactory & May cause minor breathing discomfort to sensitive people. \\
\hline $101-200$ & $\begin{array}{l}\text { Moderately } \\
\text { polluted }\end{array}$ & $\begin{array}{l}\text { May cause breathing discomfort to people with lung disease such as asthma and discomfort to } \\
\text { people with heart disease, children and older adults. }\end{array}$ \\
\hline $201-300$ & Poor & $\begin{array}{l}\text { May cause breathing discomfort to people on prolonged exposure, and discomfort to people with } \\
\text { heart disease. }\end{array}$ \\
\hline $301-400$ & Very poor & $\begin{array}{l}\text { May cause respiratory illness to the people on prolonged exposure. Effect may be more pronounced } \\
\text { in people with lung and heart disease. }\end{array}$ \\
\hline $401-500$ & Severe & $\begin{array}{l}\text { May cause respiratory impact even on healthy people, and serious health impacts on people with } \\
\text { lung/heart disease. The health impacts may be experienced even during light physical activity. }\end{array}$ \\
\hline
\end{tabular}


population is 7 billion and about 7 million die every year because of air pollution and its attendant hazards. A lot of research is going on to make earth's air free from pollutants again. Some technology-driven solutions are presented to reduce air pollution as well its harmful effects..$\underline{7-9}$

\section{Available Solutions}

\subsection{Air Pollution Masks}

One of the several ways to prevent the adverse effects of air pollution on health is pollution mask. Various pollution masks are currently available in the market, and their costs varies from Rs.200 to Rs.2,000. They claim to filter up to almost $99 \%$ of air pollutants. Face masks filter out airborne particles and are very effective when it comes to making a difference in our efforts to prevent pollution-specific illnesses. A mask with a high-quality filter could be an effective defines against the inhalation of harmful pollutant particles as small as PM 2.5. It is also important to ensure that the mask is used carefully to get effective results and that it fits well on the face; otherwise, it will be useless. In Figure 1, several pollution masks are illustrated.

\subsection{Smart Air 10}

Smart Air builds bulky filters for homes and offices. They also provide Do-It-Yourself Air Purifiers, which are made up of two parts: a simple panel air filter and a fan. The panel filters the air that fan blows and the filtered air pushes away the polluted air and occupies the free space. This device is very effective to keep pollution levels low inside homes and offices. Placing one or two Smart Air devices at the corners in a small room could be very
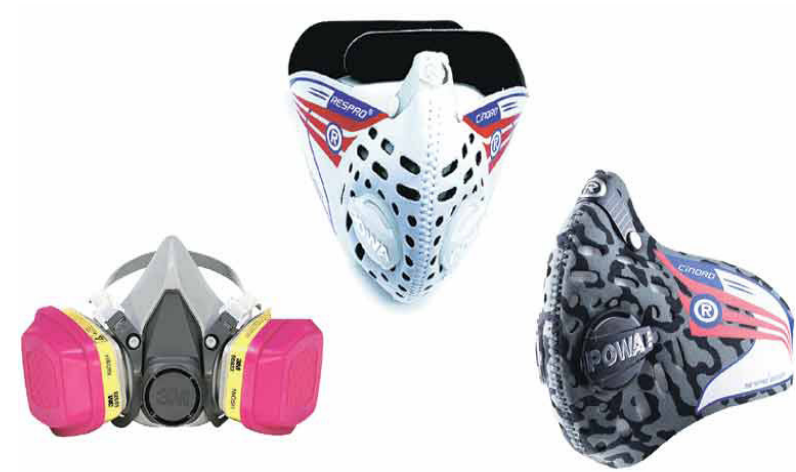

Figure 1. Several pollution masks.

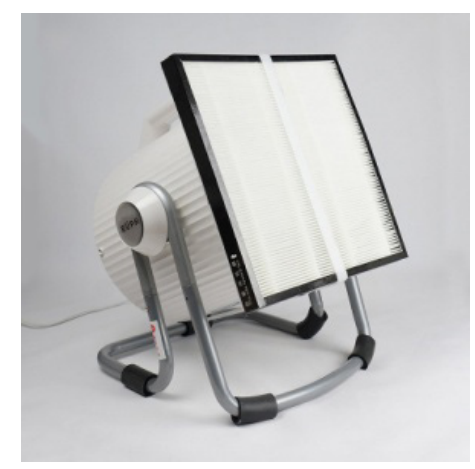

Figure 2. Smart air.

effective in removing air pollutants. Figure 2 is the picture of Smart Air.

\subsection{Air $+\underline{11}$}

Air plus (shown in Figure 3), a Singapore-based company designs and manufactures smart wearable masks. These masks are highly useful for those who have to be on the move always or cannot stay in one place for long, such as surgeons at the hospitals, daily commuters, workers construction sites, and so on.

\subsection{Kaalink $\underline{12}$}

Kaalink has been designed and developed by Graviky Labs, MIT. It converts the soot and ash produced by automobiles into black-coloured ink. The device is attached to the exhaust pipe of vehicles, collects all the soot and ash, and process them. With the help of some specific chemicals, the impurities are removed. Finally, a black-coloured ink is produced named Airink, as shown in Figures 4 and 5.

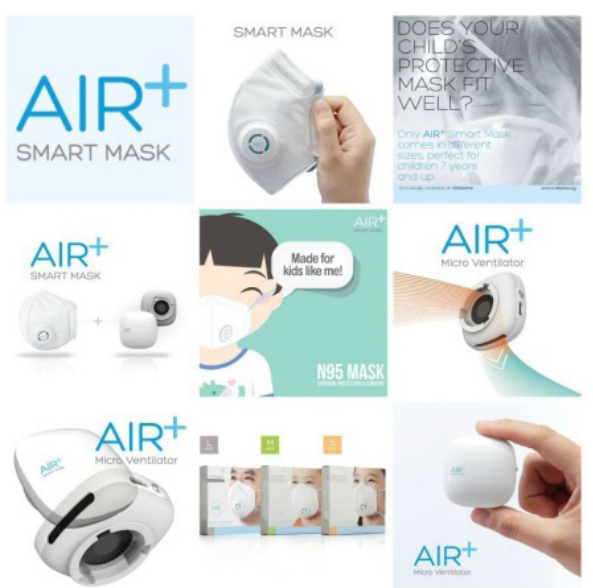

Figure 3. Air plus. 


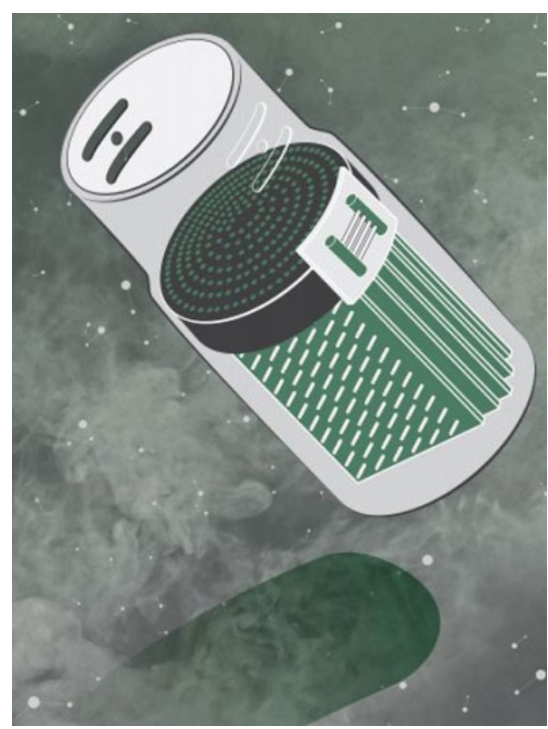

Figure 4. Kaalink.

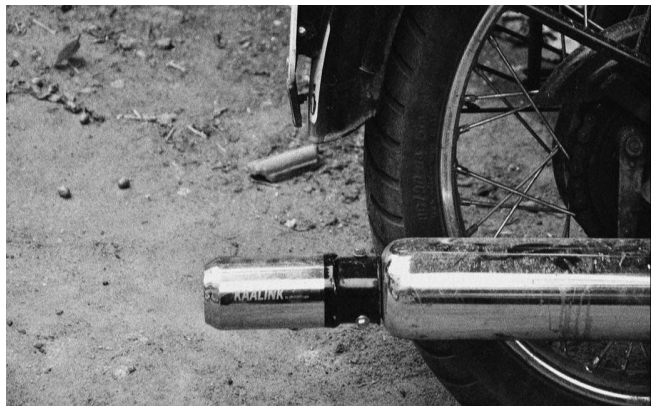

Figure 5. Kaalink attached with motor bike.

This Airink is used to make pens, markers, and paints. It can capture $95 \%$ of the expelled soot and ash from cars, which is responsible for a form of air pollution called PM 2.5. The device can produce enough ink for a $30-\mathrm{mm}$ pen it put to work for 40 to 45 minutes.

\section{Author's Proposal}

After analysing all the current solutions related to air pollution, authors have proposed a unique solution called smart air pollution mask as shown in Figures 6 and 7. The mask comes with a smart phone app that will inform its users about the pollution level in the atmosphere of their immediate vicinity or surroundings. The app is designed to give an alert signal, if the toxicity in the air increases. There is also a buzzer that produces a beep sound, if the toxicity crosses an extreme level and the quality of air becomes so low that it is not advisable for human beings to breath that air.

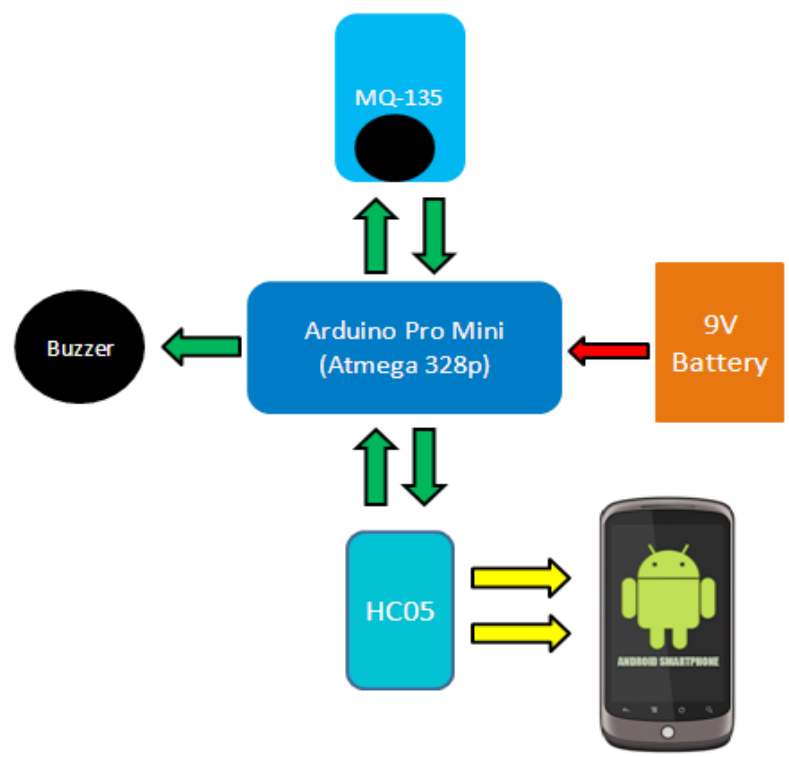

Figure 6. Block diagram representation of proposed mask.

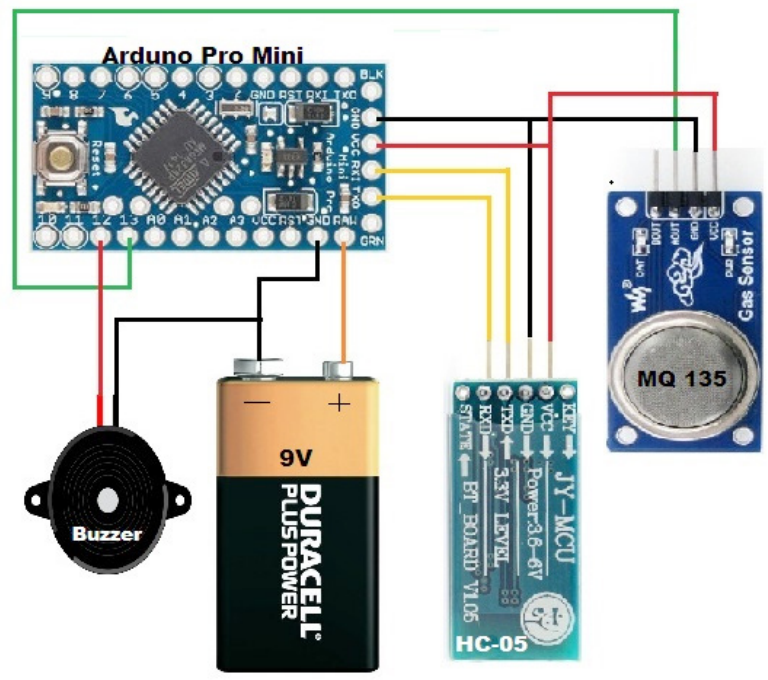

Figure 7. Diagram representation of proposed mask.

\section{Technical Scope}

\subsection{Components Used}

\subsubsection{Arduino Pro Mini (Atmega 328pAU) $\underline{13}, \underline{14}$}

Arduino Pro Mini is microcontroller that is based on Atmel Atmega328 AVR platform (shown in Figure 8). It has 14 digital input/output pins and 6 analogue input pins and total 26 pins on board. Pro Mini comes in two different versions with a dimension of $33 \times 17 \mathrm{~mm}$; one 


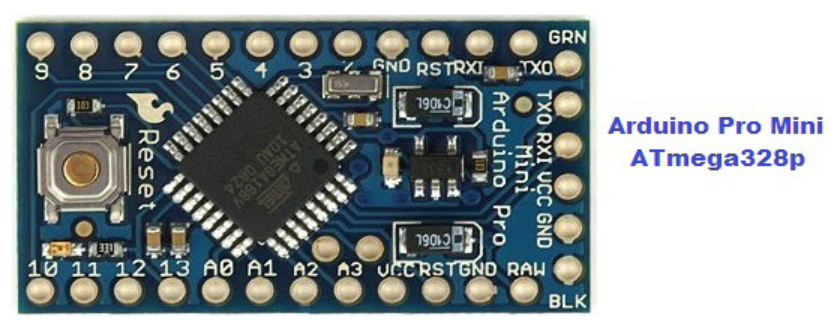

Figure 8. Arduino pro mini (Atmega 328pAU).

runs at $3.3 \mathrm{~V}$ with $8 \mathrm{MHz}$ frequency and other at $5 \mathrm{~V}$ with $16 \mathrm{MHz}$ frequency. The software used to program this device is Arduino IDE.

\subsubsection{HC-05 Bluetooth Module $\underline{15}$}

$\mathrm{HC} 05$ is a Bluetooth serial port protocol module shown in Figure 9, which is designed for wireless serial connection. The module uses Bluetooth v2.0, $3 \mathrm{Mbps}$ modulation and has a complete $2.4 \mathrm{GHz}$ radio transceiver and baseband. It uses CSR bluecore 04-external single chip Bluetooth system with CMOS technology and adaptive frequency hopping feature.

\subsubsection{MQ-135 Gas Sensor $\underline{16}$}

MQ-135 module is a gas sensor as shown in Figure 10, and is effective against pollutants such as ammonia, benzene, alcohol, and carbon dioxide. It consists of a heating element made of tin dioxide $\left(\mathrm{Sno}_{2}\right)$ and resistance, which reacts to different gases. If the toxic gases exist around the sensor, the conductivity of the sensor increases.

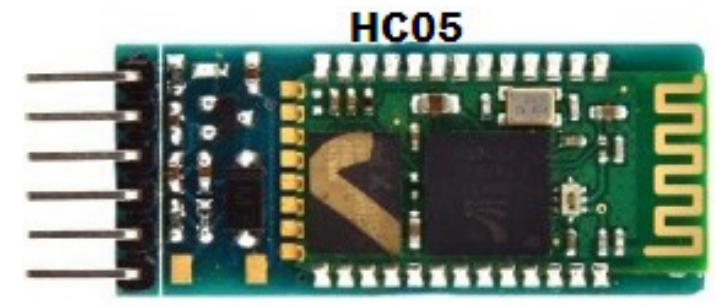

Figure 9. HC-05 bluetooth module.

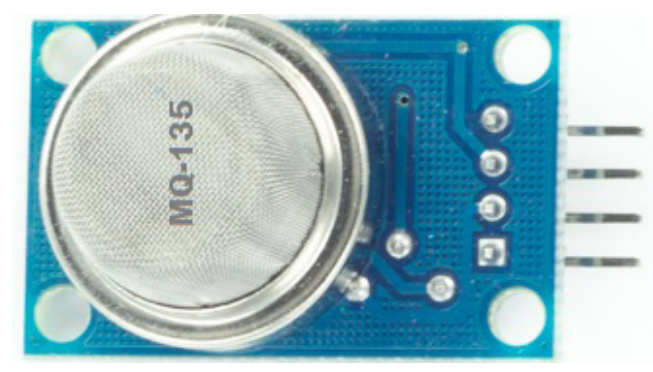

Figure 10. MQ-135 gas sensor.
This conductivity is directly proportional to the gas concentration. For efficient working, the sensor needs to be calibrated first. The time required for calibration is approximately 24 hours. The readings given by the sensor are in analogue form, so these values need to be converted into ppm (parts per million) form.

\subsubsection{Buzzer}

A buzzer (Figure 11) is an audio signal device that produces a beep sound when it is connected to an energy source. It can be electromechanical, mechanical, or piezoelectric.

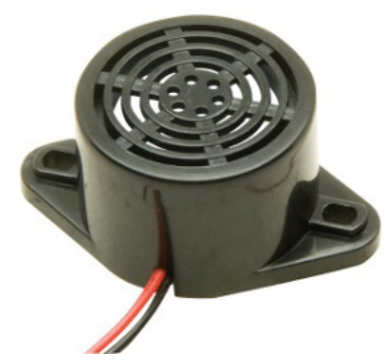

Figure 11. Buzzer.

\subsubsection{V Battery}

DC batteries (Figure 12) come in different varieties like Lithium-Polymer, Sealed Lead Acid (SLA), Lithium Ion, Alkaline, and a few more. These different batteries are used for different purposes. For example, if a circuit is having more resistance or more number of components, then it will draw more current. On the other hand, if the circuit is less resistive or having fewer components, it will draw less current. Batteries like Lithium-Polymer, SLA, and so on are more useful where there is more current requirement. And batteries like Lithium (primary), Nike Cadmium and so on are used where there is less current

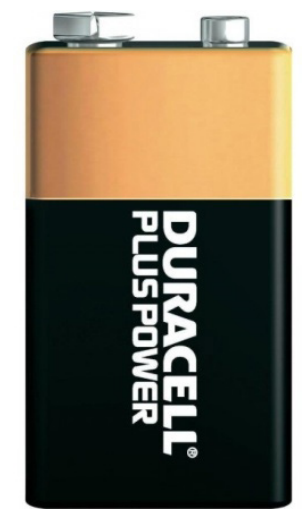

Figure 12. $9 \mathrm{~V}$ battery. 
requirement. We have made our circuit in a way that it requires less current to work. But to make circuits work for longer time, we need more current. So we are using $12 \mathrm{~V}, 2,000 \mathrm{mAH}$ Lithium Polymer batteries in our mask.

\subsection{Inside Working}

Our air pollution mask comes with a smart phone app. The smart phone app can be connected to the mask with the help of Bluetooth. This Bluetooth is based on a dedicated Bluetooth module called HC-05. HC-05 makes a wireless connection between the mask and phone and works on a free 2.4-GHz-frequency bandwidth. App also shows the pollution level of the area where the user is present. App also saves the pollution readings, so user can also go through and check previous pollution levels of the places he has already visited. The mask has an Atmel Atmega328 microcontroller that is the brain of its whole electronic circuitry. It controls all the actions taking place in the electronics inside the mask. There is a dedicated 9V DC battery inside the mask to power the electronics. When the user puts on the mask, it will reveal pollution values with the help of a dust sensor called MQ-135. This sensor is sensitive to almost all toxic gases out there in the environment, like alcohol, benzene, ozone $\mathrm{NH}_{3}, \mathrm{CO}_{2}$, and so on. As the readings from MQ-135 are raw and analogue, we can't understand these values directly. So the microcontroller converts and maps them according to the pollution values permitted in the country. The mask keeps on checking pollution values every second, and if the pollution crosses a specific limit, it produces a beep sound. This beep indicates that the pollution is increasing and the user should leave that area as soon as possible.

\section{Conclusion}

Various products are already available in the market for cleaning the air and filtering out pollutants. After analysing all the parameters and solutions available in the market, we can conclude that our proposal can be a great solution for preventing the harmful effects of air pollution and, consequently, prevent a range of diseases, including respiratory disorders, caused by air pollution.

\section{Acknowledgement}

Authors express their gratitude to the Research Mentors of Accendere Knowledge Management Services Pvt.
Ltd. for their comments on an earlier version of the manuscript. However, any errors still present in the article are all our own and should not be attributed in any way to the learned persons who reviewed or shared inputs about our study and this article.

\section{References}

1. Dalrymple GB. The age of the earth in the twentieth century: a problem (mostly) solved. Geol Soc Lond Spec Publ. 2001;190(1):205-21.

2. Air pollution causes 12 lakh deaths in India annually Delhi most polluted: Greenpeace, The Indian Express. [cited 2017 Jan 11]. https://indianexpress.com/article/india/airpollution-causes-12-lakh-deaths-in-india-annually-delhimost-polluted-greenpeace/.

3. Major air pollutants, Infoplease. [cited 2019 Jan 17]. https://www.infoplease.com/science-health/environment/ major-air-pollutants.

4. Environment Canada - Air - AQHI categories and explanations. Ec.gc.ca; 2008.

5. Technical regulation on ambient air quality index (on trial)] (PDF). Ministry of Environmental Protection of the People's Republic of China (in Chinese); 2012.

6. Central Pollution Control Board. [cited 2019 Apr 11].https:// en.wikipedia.org/wiki/Central_Pollution_Control_Board.

7. Clausen G. Ventilation filters and indoor air quality: a review of research from the International Centre for Indoor Environment and Energy. Indoor Air. 2004;14:202-7.

8. Iranpour R, Cox HH, Deshusses MA, Schroeder ED. Literature review of air pollution control biofilters and biotrickling filters for odor and volatile organic compound removal. Environ Prog. 2005;24(3):254-67.

9. Sublett JL, Seltzer J, Burkhead R, Williams PB, Wedner HJ, Phipatanakul W, Asthma \& Immunology Indoor Allergen Committee. Air filters and air cleaners: rostrum by the American Academy of Allergy, Asthma \& Immunology Indoor Allergen Committee. J Allergy Clin Immunol. 2010;125(1):32-38.

10. Smart air filters. [cited 2013 Jun 15]. https://smartairfilters. com/en/blog/how-to-make-diy-air-purifier/.

11. Smart mask. [cited 2015]. http://airplus-asia.com/ products/.

12. Kaalink. [cited 2015]. http://www.graviky.com/kaalink. html.

13. Ali AS, Zanzinger Z, Debose D, Stephens B. Open source building science sensors (OSBSS): a low-cost Arduinobased platform for long-term indoor environmental data collection. Build Environ. 2016;100:114-26.

14. Arduino pro mini. [cited 2009]. https://store.arduino.cc/ usa/arduino-pro-mini. 
15. Pahuja R, Kumar N. Android mobile phone controlled bluetooth robot using 8051 microcontroller. Int J Sci Eng Res. 2014;2(7):14-17.
16. Wijaya DR, Sarno R, Zulaika E. Gas concentration analysis of resistive gas sensor array. In: 2016 international symposium on electronics and smart devices; 2016. P. 337-42. 